\title{
PENGEMBANGAN BAHAN AJAR LISTRIK MAGNET BERBASIS ANDROID DI PROGRAM STUDI PENDIDIKAN FISIKA IKIP PGRI PONTIANAK
}

\author{
Matsun $^{1 *}$, Dochi Ramadhani ${ }^{2}$, Isnania Lestari ${ }^{2}$ \\ ${ }^{1}$ Prodi Pendidikan Fisika, IKIP PGRI Pontianak, Jl. Ampera, Pontianak \\ ${ }^{2}$ Prodi TIK, IKIP PGRI Pontianak, Jl. Ampera, Pontianak \\ *E-mail: matsunzaidan@gmail.com
}

\begin{abstract}
This study aims to: (1) develop android based magnet learning media in Physics Education Study Program; (2) to know the feasibility of learning media of Magnet Power based on androiddi of Physics Education Program. This research is a research and development $(R \& D)$ which refers to the model proposed by Thiagarajan by using 4-D model (Four-D Models) which consists of four stages, namely: define, design stage, development (develop), and dissemination stage (disseminate). The feasibility of android-based learning media is validated by material experts and media experts. Based on the result of data analysis, it is concluded that (1) the learning media of Android-based Magnet Electricity in Physics Education Study Program successfully developed with 4-D (Four-D Models) model that is define, design, develop, and disseminate. (2) learning media of Magnet Power based on android in Physics Education Study Program developed feasible to use with very good category.
\end{abstract}

Keywords: Learning Media, Magnet Electricity, Android.

IKIP-PGRI Pontianak merupakan Lembaga Pendidik dan Tenaga Kependidikan (LPTK) yang fokus dalam mencetak Guru di Kalimantan Barat, pada kurikulum KKNI Program Studi Pendidikan Fisika memposisikan Listrik Magnet sebagai salah satu mata kuliah utama, karena sarat akan aplikasi IPTEK. Namun, patut disayangkan tingkat pemahaman konsep dan prestasi belajar mata kuliah ini masih rendah. Berdasarkan identifikasi awal hasil belajar, terjadi kejenuhan akan susunan konsep di berbagai buku literatur Listrik Magnet yang tidak praktis. Informasi dari internet yang deras seharusnya dapat mempermudah belajar mandiri, justru cenderung membingungkan mahasiswa. Informasi yang tersedia secara online saat ini mengembangkan pemikiran pada tataran aplikatif yang berada pada konstruksi kognitif yang cukup tinggi, serta mengakibatkan mahasiswa justru melupakan konsep Listrik Magnet yang mendasar dan tidak dapat mengaktualisasikan konsep Listrik Magnet secara utuh. Kemajuan media internet yang dirasakan oleh mahasiswa program studi pendidikan 
fisika, yang berbeda dengan kondisi ketika mereka masih menduduki bangku SMA, berdampak terhadap kemungkinan adanya ketidaktercapaian konsep Listrik Magnet secara utuh disebabkan mahasiswa menerima informasi yang tidak tepat dari media internet. Dengan demikian, ketidaktercapaian pemahaman konsep atau bahkan miskonsepsi harus diidentifikasi dan diatasi oleh Dosen pengampu mata kuliah Listrik Magnet agar mahasiswa sebagai calon guru tidak meneruskan kesalahan yang terjadi kepada anak didiknya kelak.

Ketidaktercapaian pemahaman konsep dapat disebabkan oleh keterbatasan media pendukung pembelajaran kelistrikan dan kemagnetan yang tepat, karena menurut Poedjiadi (2005: 75) pembelajaran adalah proses interaksi yang dilakukan oleh pendidik dan peserta didik baik di dalam maupun di luar kelas dengan menggunakan media dan berbagai sumber belajar sebagai bahan kajian. Secara lebih spesifik, mata Kuliah Listrik Magnet cukup luas cakupan peranannya, tetapi menjadi tidak terpetakan dengan baik di mahasiswa karena belum dikembangkannya media virtuil yang praktis dan benar secara konsep yang mendukung media riil. Mahasiswa umumnya tidak dapat memahami perbedaan dan isi substansi Listrik Magnet dengan Elektrodinamika, maupun Elektronika. Kejenuhan akan susunan konsep di buku yang tidak praktis dan arus informasi dari internet yang deras di perguruan tinggi cenderung mengembangkan pemikiran pada tataran aplikatif yang berada pada konstruksi kognitif yang cukup tinggi, serta mengakibatkan mahasiswa justru melupakan konsep Listrik Magnet yang mendasar. Hal ini memicu pemahaman konsep dan prestasi belajar Listrik Magnet yang rendah pada tahun akademik 2015/2016. Oleh karena itu, dibutuhkan media yang tepat untuk meningkatkan pemahaman konsep mahasiswa.

Keterbatasan inovasi media virtuil yang praktis dan dapat memetakan konsep pada pembelajaran Listrik Magnet perlu di atasi di tingkat perkuliahan oleh Dosen pengampu mata kuliah Listrik Magnet, salah satunya dengan pengembangan media pembelajaran yang tepat, karena kualitas pembelajaran merupakan efektif tidaknya proses belajar mengajar dalam mencapai tujuan pembelajaran. Karuru (2001) menyatakan bahwa salah satu upaya meningkatkan kualitas proses pembelajaran di kelas adalah dengan pengembangan media pembelajaran. Penggunaan suatu media sebagai salah satu perangkat pembelajaran tanpa didukung perangkat pembelajaran lainnya yang mendukung sintaks pembelajaran akan menyebabkan ketimpangan dalam pembelajaran dan tidak efektif. Bahan ajar biasa dikemas dalam bentuk buku, tetapi seiring perkembangan zaman, bahan ajar juga disediakan dalam bentuk elektronik atau lebih dikenal dengan mobile bahan ajar. Bahan ajar listrik magnet dikembangkan dalam bentuk aplikasi mobile memungkinkan kemudahan untuk dibawa kemana saja. Bahan ajar listrik magnet dalam bentuk aplikasi seperti ini bisa memiliki lebih dari satu fitur, yakni tersedia tes online, animasi, serta materi. 
Android merupakan salah satu sistem operasi mobile yang tumbuh di tengah sistem operasi lain yang berkembang saat ini. Menurut Gargenta (2011:10), Android adalah platform komprehensif bersifat open source yang dirancanag untuk perangkat mobile. Bahan ajar listrik magnet dikembangkan dalam bentuk aplikasi android, karena sistem operasi android merupakan sistem operasi yang sedang berkembang pesat di pasaran. Jubilee (2013:13) melakukan survei pada bulan maret 2013 yakni, Android menguasai pasar dengn jumlah penjualan mencapai $37,19 \%$ selanjutnya iOS $27,18 \%$, Blackberry 3,2\%, dan Symbian 7,98\%.

Bahan ajar Listrik Magnet berbasis android perlu disempurnakan agar sesuai dengan kultur dan ciri khas Kalimantan Barat. Hal ini berkaitan dengan konsep yang akan dibangun. Konsep akan mudah diterima dan bertahan lama bila berkaitan dengan terapan dalam kehidupan sehari-hari dalam kemasan yang menarik. Bila substansi ini terintegrasi dengan Android harapannya mahasiswa akan berprestasi dan mumpuni dalam memahami serta mengaktualisasikan konsep. Dengan demikian, pengembangan bahan ajar listrik magnet berbasis android harus disesuikan bahasa, dan kebudayaan Kalimantan Barat khusunya bagi mahasiswa IKIP-PGRI Pontianak.

Agar lebih terarah, perangkat pembelajaran yang akan dikembangkan dan menjadi fokus dalam peneilitian ini adalah bahan ajar Listrik Magnet berbasis android dikembangkan dalam bentuk aplikasi android dan berperan sebagai suplemen pembelajaran. Bahan ajar membahas mengenai materi listrik magnet, animasi, dan test. Adapun cakupan materi Listrik magnet yang berkaitan dengan pengembangan adalah materi Elektrostatika; Medan Listrik; Arus Listrik; Bahan Dielektrik; dan Induksi Elektromagnetik. Pengembangan bahan ajar akan diikuti dengan pengembangan perangkat pendukung pembelajaran lainnya seperti satuan acara perkuliahan (SAP), lembar kegiatan mahasiswa (LKM), dan instrumen evaluasi.

\section{METODE}

Penelitian ini dilakukan di IKIPPGRI Pontianak pada program studi Pendidikan Fisika. Pengembangan Bahan Ajar Listrik Magnet berbasis Android difokuskan pada mahasiswa pendidikan fisika Semester V Tahun Akademik 2016/2017 kelas A Pagi dan A Sore.

Definisi operasionalnya dalam penelitian ini, yaitu media pembelajaran yang dimaksud dalam penelitian ini adalah media pembelajaran pada mata kuliah Listrik Magnet yang berbasis android yang sesuai dengan kultur dan ciri khas Kalimantan Barat.

Sesuai dengan tujuan umum penelitian yaitu mengembangkan bahan ajar Listrik Magnet berbasis Android, maka penelitian ini digolongkan ke dalam penelitian pengembangan.

Desain penelitian yang digunakan adalah desain penelitian Research and Development approach ( $\mathrm{R} \& \mathrm{D})$ dengan menggunakan model 4-D (Four-D Models) yang terdiri dari empat tahap, yaitu: tahap pendefinisian (define), tahap 
perancangan (design), tahap pengembangan (develop), dan tahap pendiseminasian (disseminate) (Thiagarajan, Semmel, \& Semmel, 1974: 5-9). Model pengembangan media pembelajaran ini dipilih berdasarkan batas tingkat pemahaman dan kemampuan peneliti dalam hal pengembangan media pembelajaran.

Teknik pengumpulan data yang digunakan dalam penelitian ini adalah teknik komunikasi tidak langsung dengan alat pengumpul data angket validasi. Angket validasi terdiri dari angket validasi ahli materi dan ahli media yang dibuat berdasarkan skala Likert.

Data hasil validasi ahli materi dan media dihitung dan dikategorikan kedalam rentang nilai 4 dengan kategori yaitu: (4) sangat baik, (3) baik, (2) cukup baik, dan (1) kurang baik. Rentang nilai penilaian hasil validasi oleh ahli materi dan media kemudian dipersentasekan, persentase hasil validasi ahli materi dan media disajikan dalam Tabel 1 (Riduwan, 2010).

Tabel 1. Rentang Kategori Nilai Hasil Validasi Ahli Materi dan media

\begin{tabular}{lll}
\hline No. & $\begin{array}{l}\text { Interval } \\
\text { Nilai } \%\end{array}$ & Kategori \\
\hline 1. & $76-100$ & Sangat Baik \\
2. & $51-75$ & Baik \\
3. & $26-50$ & Cukup Baik \\
4. & $0-25$ & Kurang Baik \\
\hline
\end{tabular}

\section{HASIL DAN PEMBAHASAN}

Model pengembangan media pembelajaran berbasis android ini dipilih berdasarkan batas tingkat pemehaman dan kemampuan peneliti dalam hal pengembngan media pembelajaran.
Deskripsi dari masing-masing tahap adalah sebagai berikut:

\section{Tahap Pendefinisian (Define)}

Tujuan tahap adalah untuk menetapkan dan mendefinisikan syarat-syarat pembelajaran. Dalam menentukan syarat-syarat pembelajaran diawali dengan analisis tujuan dari batasan bahasan.

Analisis ujung depan bertujuan untuk memunculkan dan menetapkan masalah dasar yang dihadapi dalam pembelajaran listrik magnet sehingga dibutuhkan pengembangan media pembelajaran berbasis android. Analisis peserta didik merupakan telaah karakteristik mahasiswa yang meliputi tingkat perkembangan kognitif, kemampuan, dan latar belakang sosial budaya mahasiswa. Analisis tugas merupakan kumpulan prosedur untuk menentukan isi dalam satuan pembelajaran dengan merinci isi materi ajar secara garis besar. Analisis konsep merupakan identifikasi konsep-konsep utama yang akan diajarkan dan menyusun secara sistematis serta mengaitkan satu konsep dengan konsep lain yang relevan. Hasil analisis tugas dan analisis konsep digunakan sebagai acuan untuk merumuskan indikator pencapaian hasil belajar dan tujuan pembelajaran yang dinyatakan dengan tingkah laku sebagai penjabaran dari standar kompetensi dan kompetensi dasar di silabus.

Tahapan awal pengembangan perangkat dilakukan dengan menetapkan dan mendefinisikan kebutuhan-kebutuhan di dalam proses pembelajaran. Sebagai langkah awal, yaitu: mendefiniskan tujuan pembelajaran, membatasi materi pelajaran yang disampaikan, mempelajari kesesuaian kebutuhan 
pembelajaran dengan kurikulum KKNI, tahap perkembangan peserta didik, kondisi pembelajaran. Permasaalahan yang terjadi pada pembelajaran listrik magnet yang dapat diidentifikasi adalah pemahaman dan aplikasi konsep mahasiswa berkaitan materi yang dibahas, dan informasi yang tersedia secara online saat ini mengembangkan pemikiran pada tataran aplikatif yang berada pada konstruksi kognitif yang cukup tinggi, serta mengakibatkan mahasiswa justru melupakan konsep listrik magnet yang mendasar dan tidak dapat mengaktualisasi konsep listrik magnet secara utuh.

Permasalahan

tersebut

dijadikan dasar dalam menentukan media pembelajaran yang dibutuhkan agar dalam penerapannya tepat dan efisien. Media pembelajaran dirumuskan melalui perancangan indikator pencapaiana hasil belaja, media, format media, pilihan bahasa, tugas, dan pemilihan konsep yang akan ditekankan pada mahasiswa. Media pembelajaran berbasis android dipilih karena android merupakan salah satu sistem operasi mobile yang tumbuh di tengah sistem operasi lain yang berkembang saat ini. Android adalah platform komprehensif bersifat open source yang dirancanag untuk perangkat mobile. Bahan ajar listrik magnet dikembangkan dalam bentuk aplikasi android, karena sistem operasi android merupakan sistem operasi yang sedang berkembang pesat di pasaran. Sehingga banyak sekali mahasiswa yang menggunakan aplikasi android. Dimaksudkan untuk meningkatkan motivasi dan partisifasi aktif mahasiswa. Mahasiswa juga diharapkan mengetahui produk teknologi yang relevan dengan kehidupan sehari-hari sehingga mendukung pemahaman mahasiswa terhadap materi yang dibahas.

\section{Tahap Perancangan (Design)}

Tahap ini memiliki tujuan untuk menyiapkan prototipe media pembelajaran, dengan langkah yaitu:

a) Penyusunan tes (Criterian-test conctruction), merupakan langkah awal yang menghubungkan antara tahap pendefinisian dengan tahap pengembangan. Tes disusun berdasarkan hasil perumusan indikator pencapaian hasil belajar, b) Pemilihan media yang sesuai tujuan untuk menyampaikan materi pelajaran (media selection), c) Pemilihan format (format selection), dilakukan dengan mengkaji dengan format-format yang ada dan disesuaikan dengan kurikulum yang berlaku, d) Menyusun rancangan awal media pembelajaran.

Tahap perancangan yaitu pemilihan media dan desain awal perangkat dapat dijelaskan sebagai berikut:

\section{a) Penyusunan Instrumen Tes Hasil Belajar (Criterian-Test Construction)}

Sesuai dengan tujuan penelitian ini yaitu dikembangkan instrumen evaluasi (tes) pemahaman konsep. Instrumen tes disusun berdasarkan hasil perumusan indikator pencapaian pemahaman konsep dan tujuan pembelajaran. Tes merupakan salah satu alat untuk mengukur terjadinya peningkatan pemahaman konsep pada mahasiswa setelah berlangsung proses belajar mengajar dengan media pembelajaran listrik magnet berbasis android sehingga desain tes yang digunakan adalah pre-post test design.

Selain instrumen tes

pemahaman konsep, untuk 
mengetahui gambaran pembelajaran dengan menerapkan media pembelajaran listrik magnet berbasis android dikembangkan pula instrumen evaluasi pembelajaran dalam bentuk yang lain. Bentuk instrumen yang dimaksud adalah angket pendapat mahasiswa terhadap media pembelajaran berbasis android. Angket ini disebarkan di akhir keseluruhan kegiatan pembelajaran.

\section{b) Pemilihan Media Dan Sumber Belajar (Media Selection)}

Kegiatan pemilihan media pembelajaran disesuaikan dengan hasil analisis tugas, karakteristik mahasiswa, kemampuan dosen, serta kondisi lingkungan. Dari Media pembelajaran listrik magnet berbasis android diharapkan mahasiswa dapat:

(1) Melibatkan diri dalam proses pembelajaran dengan suasana yang menyenangkan tanpa perasaan terpaksa.

(2) Belajar berhadapan langsung dengan melakukan kegiatan (learning by doing) dan tanpa terlalu bergantung pada dosen.

(3) Belajar menemukan fakta yang ditunjukkan gejala-gejalanya melalui eksperimen dan mengetahui aplikasinya dalam kehidupan sehari-hari.

c) Pemilihan Format dan Desain Awal Media (Format Selectiaon \& Initial Design)

Hasil analisis isi, analisis tugas, penyusunan indikator, tujuan pembelajaran, serta pemilihan media dan sumber belajar diimplementasikan dalam media pembelajaran yang akan digunakan dalam penelitian ini. Sesuai dengan tujuan khusus dari penelitian untuk menguji media yang efektif, maka perlu dilakukan design terhadap media pembelaajran berbasis android.

Menurut Pocatilu (2010: 177) Android merupakan suatu software (perangkat lunak) yang digunakan pada mobile device (perangkat berjalan) yang meliputi sistem operasi, middleware dan aplikasi inti”. Android menurut Jubilee (2013: 2) adalah sebuah sistem operasi untuk smartphone dan tablet. Sistem operasi dapat diilustrasikan sebagai jembatan antara piranti (device) dan penggunaannya, sehingga pengguna dapat berinteraksi dengan device-nya dan menjalankan aplikasi-aplikasi yang tersedia pada device. Referensi lain ditemukan bahwa Bousmah, dkk (2015: 1-5) berpendapat mengenai Android merupakan sistem operasi berbasis Linux yang khusus untuk perangkat bergerak seperti smartphone atau tablet.Sistem operasi Android ini bersifat open source sehingga banyak sekali programmer yang berbondongbondong membuat aplikasi maupun memodifikasi sistem ini. Para programmer memiliki peluang yang sangat besar untuk terlibat mengembangkan aplikasi Android karena alasan open source tersebut. Sebagian besar aplikasi yang terdapat dalam Play Store bersifat gratis dan ada juga yang berbayar.

\section{Tahap Pengembangan (Develop)}

Pada tahap pengembangan bentuk awal (Develop) dari media pembelajaran Listrik Magnet berbasis Android yang dilakukan adalah membuat media pembelajaran berbasis Android sesuai dengan story board yang telah dibuat pada tahap perancangan. Pembuatan media pembelajaran Listrik Magnet berbasis android yang telah dilakukan dalam 
penelitian ditunjukkan dengan beberapa tampilan visualisasi gambar secara langsung. Produk yang telah dikembangkan berupa media pembelajaran Listrik Magnet Berbasis Android kemudian dilakukan validasi oleh validator untuk menilai kelayakan sebelum uji coba lapangan sekala kecil. Proses validasi meliputi validasi materi oleh ahli media dan hasil validasinya bisa dilihat pada tabel dibawah ini.

Tabel 2. Hasil Validasi Ahli Materi

\begin{tabular}{llcccc}
\hline No. & Aspek Penilaian & $\begin{array}{c}\text { Perolehan } \\
\text { skor }\end{array}$ & $\begin{array}{c}\text { Skor } \\
\text { maksimum }\end{array}$ & $\begin{array}{c}\text { Persentase } \\
\text { Skor }(\%)\end{array}$ & Keterangan \\
\hline 1 & Bahasa & 12 & 15 & 80 & Sangat Baik \\
2 & Efek bagi strategi & 22 & 30 & 73 & Baik \\
3 & Rekayasa perangkat & 27 & 30 & 90 & Sangat Baik \\
& lunak & 37 & 45 & 82 & Sangat Baik \\
\hline & Tampilan & Rata-rata & & 81 & Sangat Baik \\
\hline
\end{tabular}

Tabel 3. Hasil Validasi Ahli Media

\begin{tabular}{|c|c|c|c|c|c|}
\hline No. & Aspek Penilaian & $\begin{array}{c}\text { Perolehan } \\
\text { skor }\end{array}$ & $\begin{array}{c}\text { Skor } \\
\text { maksimum }\end{array}$ & $\begin{array}{c}\text { Persentase } \\
\text { Skor }(\%)\end{array}$ & Keterangan \\
\hline 1 & Relevansi & 17 & 20 & 85 & Sangat Baik \\
\hline 2 & $\begin{array}{l}\text { Pengorganisasian } \\
\text { materi }\end{array}$ & 21 & 28 & 84 & Sangat Baik \\
\hline 3 & Evaluasi latihan soal & 29 & 32 & 90,6 & Sangat Baik \\
\hline 4 & Bahasa & 6 & 8 & 75 & Baik \\
\hline 5 & $\begin{array}{l}\text { Efek bagi strategi } \\
\text { pembelajaran }\end{array}$ & 16 & 20 & 80 & Sangat Baik \\
\hline \multicolumn{4}{|c|}{ Rata-rata } & 82,92 & Sangat Baik \\
\hline
\end{tabular}

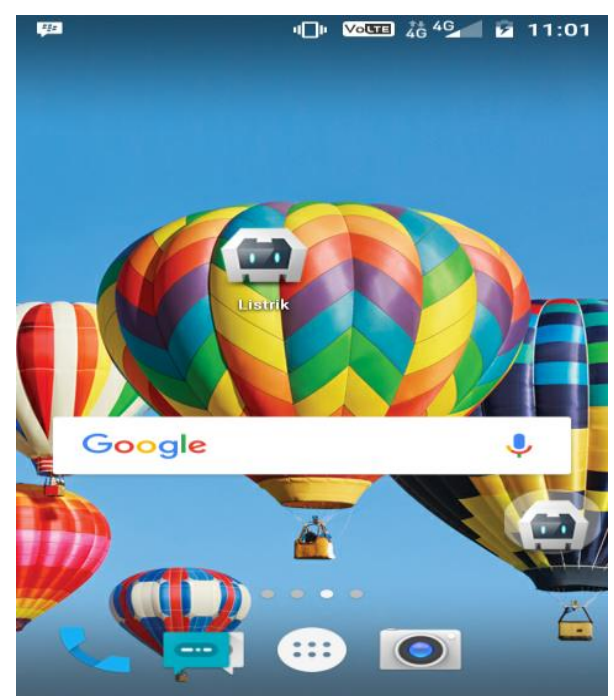

Gambar 1. Tampak Media Pada Android

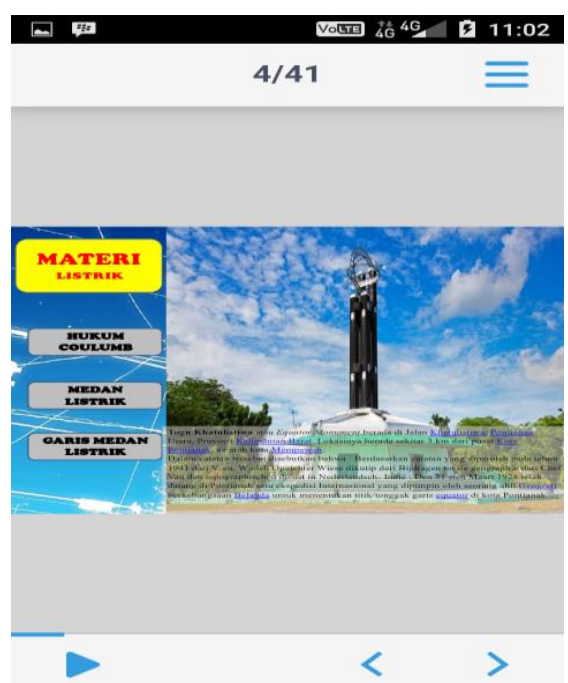

Gambar 2. Materi Listrik Magnet Pada Media Android 
Tahap Pendiseminasian (Disseminate)

Tahap terakhir dari pengembangan produk yaitu revisi produk akhir dari hasil ujicoba pemakaian oleh pengguna. Revisi produk akhir didasarkan dari saran dan masukan yang diperoleh dari ujicoba pemakaian yang dilakukan di kelas A Pagi Semester 5 IKIP PGRI Pontianak. Revisi yang dilakukan pada produk media pembalajaran pada tahap akhir meliputi kejelasan materi dan media serta beberapa pembenaran pada penulisan naskah soal dengan gambar. Pada tahap ini media pembelajaran berbasis android disebarluaskan kepada mahasiswa yang mempelajari listrik magnet.

\section{SIMPULAN DAN SARAN}

Tahapan yang dilakukan berkenaan dengan pengembangan media pembelajaran Listrik Magnet berbasis android dengan menggunakan model Four-D Models (4-D) adalah tahapan define, design, develop, dan disseminate. tahapan define meliputi Analisis Ujung Depan (Front-end Analysis), Analisis Mahasiswa (Learner Analysis), Analisis Tugas (Task Analysis), Analisis Konsep (Concept Analysis), dan Perumusan Tujuan Pembelajaran (Specifying Instructional Objectives). Tahapan design meliputi Penyusunan tes (Criterian-test conctruction), Pemilihan media yang sesuai tujuan untuk menyampaikan materi (media selection), Pemilihan format (format selection), Menyusun rancangan awal perangkat (initial design). Tahapan develop meliputi validasi ahli materi, media dan angket respon mahasiswa. Tahapan disseminate meliputi uji penggunaan media pembelajaran Listrik Mgagnet Berbasis Android kepada Mahasiswa semester 5 kelas A pagi IKIP PGRI Pontianak. Beberapa contoh hasil pengembangan yang didapatkan adalah pendefinisian media pembelajaran berbasis androd yang sesuai dengan fokus permasalahan dan arah pengembangan. Adapun dari data penelitian didapatkan nilai ahli meteri dengan rata-rata 81 (sangat Baik) dan ahli media dengan ratarata nilai 82.92 (sangat baik) sehingga media pembelajaran Listrik Magnet Berbasis Android Layak digunakan dengan keteria sangat baik.

Diharapkan untuk menyempurnakan penelitian diperlukan tahap pendiseminasian (disseminate), dimana pada tahap ini digunakan media pembelajaran listrik magnet berbasis android yang telah dikembangkan pada skala yang lebih luas, misalnya diperguruan tinggi lain, dan oleh pengajar yang lain, agar efektivitas penggunaan di dalam proses belajar mengajar dan pembuktian bahwa perangkat yang dikembangkan sangat meyakinkan hasilnya dan benar-benar efektif.

\section{DAFTAR PUSTAKA}

Bousmah, Mohammed dkk. (2015). MORAVIG: An Android Agent for the Project Mobile eLearning Session. International Journal of Computer Applications, Vol. 113, No. 15, 12-19. 
Jubilee (2013). Step by Step Ponsel Android, Jubilee Enterprise. Jakarta: Elex media Komputindo.

Gargenta. (2011). Learning Android. .O'Reilly Media Inc.

Karuru, Perdy. (2001). Penerapan Pendekatan Keterampilan Proses dalam Setting Pembelajaran Kooperatif Tipe STAD untuk Meningkatkan Kualitas Belajar IPA Siswa SLTP. Jurnal Penelitian. Jakarta: FKIP Universitas Terbuka. Retrieved Juli 30, 2007, from www.depdiknas. go.id.

Pocatilu, Paul. (2010). Developing Mobile Learning Applications for Android using Web Services. Informatica Economica, Vol.14, No.3, 106115.
Poedjiadi. (2005). Sains Teknologi Masyarakat. Bandung: Remaja Rosdakarya.

Riduwan. (2010). Skala Pengukuran Variabel-Variabel Penelitian. Bandung: Alfabeta.

Thiagarajan, S., Semmel, D. S., dan Semmel, M. L. (1974). Instructional Development for Training Teachers of Exceptional Children. Broomington:IndianaUniversity. 